\title{
Values in social responsibility in higher education
}

\author{
"In times of crisis, only imagination is more important than knowledge" \\ Albert Einstein
}

At present, society that is immersed in a maelstrom of changes in all areas, demanding new adaptations to the human group to constitute links that build the development of the population and people in a particular way requires appreciation of the importance of higher education as the foundation of a more prosperous, just and supportive society.

Tünnermann ${ }^{1}$ points out that higher education in this century demands flexibility in its "doing" and "doing", reforming its structures and working methods and integrating a prospective vision where imagination and creativity inspired by solidarity, equity and respect for the environment - be the basis of the learning process of the people; a process that would facilitate access to the globalized world of work and, as an active member, to reach the Millennium Development Goals by 2030, which are proposals for the great problems facing the population in this age, especially Latin America and El Salvador. Caribbean.

In 2008, the Regional Conference on Higher Education in Latin America and the Caribbean, held as a prelude to the World Conference on Higher Education held in Paris in 2009, highlights the need for higher education to contribute to democratic and tolerant coexistence, in a spirit of solidarity and cooperation among members; It also fosters opportunities for all humanity, with an emphasis on vulnerable populations, to contribute to the creation of knowledge, social and productive transformation of societies. ${ }^{2}$

Already at the World Conference in Paris, the social responsibility of higher education institutions is highlighted, specifying, among other points, that they [...] should contribute to the formation of citizens with ethical principles, committed to the construction of peace, human rights and values [... . $^{3}$ Need that is more latent in the peoples of the planet where inequities constitute a breach to live with dignity and could be reduced by enhancing knowledge, in short, human talent. Education in the twenty-first century seeks to secure in the person the security that even when immersed in the changes that are happening, their cultural integrity, their human essence is not lost; Instead, look for tools that help you realize your personal project.

It is thus that the university is subjected to profound changes, one of them is the formation of competences understanding that this involves, in addition to the cognitive and procedural aspects, attitudinal aspects in which the values that must cement or build the student as being human being. According to Casares et al., ${ }^{4}$ citing Jover et al., they refer that competences constitute a specific category of individual characteristics that have close ties to values, ethics and acquired knowledge.

From this holistic view, competence is a set of knowledge, attitudes, values and skills necessary to analyze specific situations with critical thinking that allows a satisfactory performance from a human perspective, in which attributes such as solidarity, benevolence, tolerance, compassion by the neighbor reflect that the professional, in addition to learning to be, learned to coexist.

In that sense, Millennium educators have a responsibility to train people with a broad and flexible mentality and deep convictions; people willing to serve humanity wherever they are, ${ }^{5}$ which requires a formation with a strong ethical, value and scientific content to get out of the moral underdevelopment in which humanity is submerged or, as Garcia Serrano refers to quoting Kant, ${ }^{6}$ the education of duty will break mental structures based on facilitation, will lead to the fulfillment of obligations, respect for the human rights of different types of diversity, the construction of a world in which our actions allow harmonious coexistence and sustainable, which could be translated into what Morín, cited by Romero et al., ${ }^{5}$ [...] calls the possible but not yet probable Fifth Birth, would be the birth of humanity, which would make us abandon the planetary iron age of the prehistory of the human spirit, that would civilize the earth and see the birth of the world-society [...]. 
Achieving moral prosperity implies a constellation of virtues, as Pope John Paul II pointed out: laboriousness, order, honesty, initiative, saving, spirit of service, fulfillment of the word engaged; in short, love for a job well done. 7 The work of the educator of this century is arduous, since not only must he achieve the training of his students, he must also train people, make them grow and develop in them capacities for life. education must focus on human formation [...] the educator for the twenty-first century, writes Colombian professor Alvaro Recio, will be an educator-researcher with a deep human and social formation, so that he becomes an agent of change for himself, his students and the surrounding community [...]. ${ }^{1}$

\section{REFERENCIAS BIBLIOGRÁFICAS}

1. Tünnermann BC. El rol del docente en la educación superior del siglo XXI [internet]. México: UNAM; 20 nov 2009 [citado 10 may 2017]. p.17. Disponible en: https://es.scribd.com/document/264718933/EL-ROL-DEL-DOCENTEEN-LA-EDUCACION-SUPERIOR-DEL-SIGLO-XXI

2. Conferencia Regional sobre la Educación Superior en América Latina y El Caribe (CRES). Declaraciones y Plan de Acción. Perfiles Educativos [serie de internet]. Ene 2009 [citado 02 may 2017]; 31 (125): 90-108. Disponible en: http://www.scielo.org.mx/pdf/peredu/v31n125/v31n125a7.pdf

3. UNESCO. Conferencia Mundial sobre la Educación Superior-2009: La nueva dinámica sobre la educación superior y la investigación para el cambio social y desarrollo [internet]. Paris: UNESCO; 08 jul 2009 [citado 10 de abr 2017]. p.09. Disponible en: http://www.unesco.org/education/WCHE2009/comunicado_es.pdf

4. Casares GPM, Carmona OG, Martínez-Rodríguez FM. Valores profesionales en la formación universitaria. REDIE [serie de internet]. Ene 2010 [citado 15 de abr 2017]; 12(Esp): [cerca de 15c laudas]. Disponible en: http://www.scielo.org.mx/pdf/redie/v12nspe/v12nspea4.pdf

5. Romero IPJ (Coord). Pedagogía de la humanización [internet]. Colombia: Universidad San Buenaventura, Facultad de Educación; may 2006 [citado 02 de may 2017]. p. 28. Disponible en: http://biblioteca.usbbog.edu.co:8080/Biblioteca/BDigital/36711-01.pdf

6. García SSE. Referentes epistemológicos para la competencia: actuar éticamente como ciudadano y profesional. Rev Temas [serie de internet]. 2016 [citado 21 may 2017]; 3(10): 111-120. Disponible en: https://dialnet.unirioja.es/descarga/articulo/5894412.pdf.

7. Pablo II J. Discurso del Santo Padre Juan Pablo II a los delegados de la comisión económica para América Latina y El Caribe (CEPALC) [internet]. Santiago de Chile: LÓsservatore Romano; abr 1987 [citado 16 de abr 2017 ]. p. 02. Disponible en: $\quad$ https://w2.vatican.va/content/john-paul-ii/es/speeches/1987/april/documents/hf jpii_spe_19870403_cepalc-chile.html

1 Escuela de Enfermería Padre Luis Tezza afiliada a la Universidad Ricardo Palma, Lima-Perú.

a Licenciada en Enfermería.

a Magister en Enfermería, con mención en Gestión Administrativa. 